\title{
Effects of AminoethoxyVinylGlycine (AVG) Spraying Time at Preharvest Stage to Ethylene Biosynthesis of Cavendish Banana (Musa AAA)
}

\author{
Nguyen Van Toan (Corresponding author) \\ Hue University of Agriculture and Forestry \\ 102 Phung Hung st., Hue city, Vietnam
}

Tel: 84-543-514-294 E-mail: toanbq@yahoo.com

Le Van Hoang

Dong A University, 204B Ly Tu Trong st., Da Nang city, Vietnam

Tel: 84-913-443-777 E-mail: hoanglv@donga.edu.vn

Le Van Tan (Corresponding author)

Hochiminh City University of Industry

12 Nguyen Van Bao st., Hochiminh city, Vietnam

Tel: 84-838-946-268_E-mail: tanhuaf@yahoo.com

Chu Doan Thanh

Fruit and Vegetable Research Institute

Trau Qui village, Gia Lam district, Hanoi, Vietnam

Tel: 84-912-187-834 E-mail: thanhc@missouri.edu

Le Van Luan

Hue University of Agriculture and Forestry

102 Phung Hung st., Hue city, Vietnam

Tel: 84-543-514-294Ｅ-mail: luan.1v@gmail.com

This research was financed by Viet Nam Institute of Vegetables Research, Vietnam

\begin{abstract}
This research aimed to identify the possible effects of the moment of Aminoethoxyvinylglycine (AVG) application during near harvest period on ethylene biosynthesis and find out the most appropriate possible way to control the process for maximum prolonging the postharvest shelf - life of bananas. Results indicated that the most appropriate moment of AVG application is from the $74^{\text {th }}$ to $78^{\text {th }}$ days after formation of the last hand of a bunch has been finished as AVG showed some inhibition effects on ACC, ACC oxydase and ethylene synthesis. ACC, ACC oxydase and ethylene production of the fruits sprayed with $A V G$ of $0.8 \mathrm{~g} / \mathrm{l}$ on the $78^{\text {th }}$ day, harvested and stored at $13 \pm 1^{\circ} \mathrm{C}$ for four weeks were $1.09\left(\mathrm{nmol} \mathrm{C}_{2} \mathrm{H}_{4} \cdot \mathrm{g}^{-1}\right), 0.44\left(\mathrm{nmol} \mathrm{C} \mathrm{H}_{4} \cdot \mathrm{g}^{-1} \cdot \mathrm{h}^{-1}\right)$ and $0.11\left(\mu \mathrm{C}_{2} \mathrm{H}_{4} \cdot \mathrm{kg}^{-1} \cdot \mathrm{h}^{-1}\right)$ respectively while the ACC, ACC oxydase and ethylene production of non - treated fruits stored in the same conditions were $6.89\left(\mathrm{nmol} \mathrm{C}_{2} \mathrm{H}_{4} \cdot \mathrm{g}^{-1}\right)$, $2.18\left(\mathrm{nmol} \mathrm{C}{ }_{2} \mathrm{H}_{4} \cdot \mathrm{g}^{-1} \cdot \mathrm{h}^{-1}\right)$ and $1.48\left(\mu \mathrm{C}_{2} \mathrm{H}_{4} \cdot \mathrm{kg}^{-1} \cdot \mathrm{h}^{-1}\right)$ respectively.
\end{abstract}

Keywords: AVG, ACC, ACC oxydase, Ethylene biosynthesis

\section{Introduction}

Banana is the most popular fruit in Vietnam. It has been cultivated in the country for thousands of years. Banana ranks first among the fruits trees in both cultivation area and production. Banana production in the country is 
estimated as much as 1.35 million tons annually. Among the different varieties being grown in Vietnam, the Cavendish one (Musa AAA) is the most popular that makes up more than $80 \%$ of total banana production in the country.

Ethylene is a plant hormone that plays a special role in stimulating the ripening process of banana. Ethylene promotes the ripening of fruits and leaves senescence that leads to further damage of the fruit [Blankenship, 2000], [Tong, 2010].

There is still a litter research on identification of the relationship between ethylene biosynthesis of plants and their postharvest shelf-life. The research "Effects of Aminoethoxyvinylglycine (AVG) spraying's time at pre-harvest stage to ethylene biosynthesis of Cavendish banana (Musa AAA)", thus, has scientific and practical significance.

\section{Materials and methods}

\subsection{Materials}

Cavendish banana (Musa AAA) was harvested on the $90^{\text {th }}$ day since the flower has been cut off with had green peels, light gloss, typical firmness, smooth and round edges. The fruits were selected to be uniformed in color and firmness. Right after harvest, the fruits were immediately transported to postharvest experimental site at the Postharvest laboratory of Fruit and Vegetable Research Institute (Hanoi, Vietnam).

Carbendazim (CBZ), chemical formula $\mathrm{C}_{9} \mathrm{H}_{9} \mathrm{~N}_{3} \mathrm{O}_{2}$, with wide range of anti-fungicidal effect, particularly on apples, bananas, grapes, food crops and some vegetables. The chemical was from Hainan Zhongxin Chemical Co. Company Ltd. (China).

Amoniethoxyvinylglycine (AVG) with commercial name Retain from Valent BioSciences Corp.

\subsection{Methodology}

\subsubsection{Experimental method}

Ethylene production rate was determined with the Ethylene analyzer ICA 56 based on quantity of ethylene formed by the fruits during postharvest storage [Barker, 2002].

ACC content was determined by the method developed by Lizada and Yang, 1979 [Lizada, Yang, 1979] with modification.

ACC oxydase activity was determined by the method of Moya - León and John [Moya-León, John, 1994] with modification.

\subsubsection{Experimental design}

The experiments were repeated three times in completely randomized block design (CRBD) with single factor (time) of 5 levels, as follows:

(Control): Do not spray AVG at preharvest stage.

$\left(70^{\text {th }}\right)$ : Spraying AVG $0.8 \mathrm{~g} / 1$ on the $70^{\text {th }}$ after cutting flower.

$\left(74^{\text {th }}\right)$ : Spraying AVG $0.8 \mathrm{~g} / 1$ on the $74^{\text {th }}$ after cutting flower.

$\left(78^{\text {th }}\right)$ : Spraying AVG $0.8 \mathrm{~g} / 1$ on the $78^{\text {th }}$ after cutting flower.

$\left(82^{\text {nd }}\right)$ : Spraying AVG $0.8 \mathrm{~g} / 1$ on the $82^{\text {nd }}$ after cutting flower.

The fruits were harvested at $90^{\text {th }}$ day after the flower has been cut off, randomly placed into corrugated carton boxes with 6 hands per box. The boxes with banana stored in cool room at $13 \pm 1^{\circ} \mathrm{C}, 85-90 \% \mathrm{RH}$. Samples were taken and analyzed for ethylene production, ACC content and ACC oxydase activity.

Experiment data were statistically analyzed with the statistical package IRRISTAT 5.0 for Windows.

\section{Results and discussions}

\subsection{Effect of AVG spraying time on ethylene production of banana during postharvest storage}

AVG is an amino acid regulating ethylene biosynthesis by inhibitory of ACC synthesis activity mechanisms [McGlasson et al., 2005], [Ness and Romani, 1980]. It can strongly inhibit the SAM to ACC conversion and, therefore, can inhibit ethylene production, delay ripening and prolong "fresh" time of fruits [Capitani et al., 2002]. Figure 1 shows the fluctuations of banana ethylene production during postharvest storage. Ten days after harvest, ethylene production of all fruits (with or without AVG spraying) was not significant different. This result is quite appropriate with results previously reported by Innaba [Innaba et al., 2007] on ethylene biosynthesis of 
Japanese banana fruit.

Ethylene production of control fruits (DC2) increased rapidly and gained maximum value at $1.48 \mu 1 \mathrm{C}_{2} \mathrm{H}_{4} \cdot \mathrm{kg}^{-1} \cdot \mathrm{h}^{-1}$ on the $28^{\text {th }}$ day. Meanwhile, in the AVG-treated fruits, the peak of ethylene production occurred with some delay depends on AVG spraying time.

For different AVG spraying time treatments (at $70^{\text {th }}$ and $82^{\text {nd }}$ day), ethylene production increased slowly and the changes had positive correlation up to the $26^{\text {th }}$ day. After the $26^{\text {th }}$ day, ethylene production increased rapidly and reached maximum value on the $30^{\text {th }}$ and the $32^{\text {nd }}$ day with the values of $1.56 \mu \mathrm{C}_{2} \mathrm{H}_{4} \cdot \mathrm{kg}^{-1} \cdot \mathrm{h}^{-1}$ and $1.87 \mu 1$ $\mathrm{C}_{2} \mathrm{H}_{4} \cdot \mathrm{kg}^{-1} \cdot \mathrm{h}^{-1}$, respectively. Beyond this moment, the fruits reached their maximum maturity index and postharvest storage experiments stopped.

Meanwhile, on the part of the spraying AVG time treatments $\left(74^{\text {th }}\right.$ and $\left.78^{\text {th }}\right)$, the change of ethylene production occurred slowly and reached maximum value on the $36^{\text {th }}$ and $38^{\text {th }}$ days with 1.74 and $1.63 \mu 1 \mathrm{C}_{2} \mathrm{H}_{4} \cdot \mathrm{kg}^{-1} \cdot \mathrm{h}^{-1}$ respectively.

In conclusion, experimental results showed that time of AVG spraying at marginal harvest stage clearly affected to inhibit the activity of internal enzymes such as ACC synthesis and ACC oxydase. These enzymes played a major role in regulating production of ethylene - a hormone controlling postharvest ripening of banana.

Results showed that the most appropriate time AVG spraying is between $74^{\text {th }}$ and $78^{\text {th }}$ days after banana flower has been cut off from the bunch.

\subsection{Effect of AVG spraying time on ACC content of banana during postharvest storage}

Fruit ripening process is controlled by ethylene - a natural plant hormone that closely related to growth, development, ripening and senescence. Figure 2 describes the variation of ACC content during storage.

Figure 2 showed that the changes of ACC content of all treatments have the same pattern. At first, the change was negligible (the first 6 days), then gradually increased and reached peaks depends on different treatments. From now in, ACC content slope - wise decreased.

ACC content of all treatments with AVG spraying slowly increased, maintained at a low level in the long term (6 days). Then nearby respiratory peak, ACC content started to increase dramatically and reached the maximum value then decreases. The increase and decrease of ACC content are parallel with the increase, decrease of ethylene production.

ACC content of bananas from the $74^{\text {th }}$ and $78^{\text {th }}$ days reached maximum value more slowly than other treatments, in which ACC content of control DC2 (without AVG spraying) gained the maximum value at the earliest time on the $28^{\text {th }}$ day, following by $70^{\text {th }}$ day, reaching the maximum value $6.73 \mathrm{nmol} \mathrm{C}_{2} \mathrm{H}_{4} \cdot \mathrm{g}^{-1}$ on the $30^{\text {th }}$ day. The slowly ACC content reaches the maximum value; the longer banana ripening banana is delayed.

Experimental results showed that around time of AVG spraying at the $74^{\text {th }}$ to $78^{\text {th }}$ days after the flower cutting off the ACC formation was inhibited to lowest level. It means, the AVG spraying definitely slow down the ethylene production and should have some ripening delay effects on bananas after harvest.

\subsection{Effect of $A V G$ spraying time on ACC oxydase activity of banana during postharvest storage}

The last step of ethylene biosynthesis pathway is ACC - Ethylene conversion. This process requires presence of $\mathrm{O}_{2}$ and catalysis of ACC oxydase [Mizutani et al., 1995], [Jobling et al., 2003]. ACC oxydase is an internal enzyme playing catalytic role for ethylene formation process from ACC. When activation of ACC oxydase is higher, ethylene production is greater; fruit ripening process is quicker after harvest. The change of ACC oxydase activation during storage is represented in table 1 . The data from table 1 show that ACC oxydase activity of all treatments (with or without AVG spraying) tended to increase after 6 days storage and reached peak then gradually decreased.

Control treatment (DC2) without AVG spraying, ACC oxydase activity increased faster than other treatments, reached peak at $2.86 \mathrm{nmol} \mathrm{C}_{2} \mathrm{H}_{4} \cdot \mathrm{g}^{-1} \cdot \mathrm{h}^{-1}$ on the $26^{\text {th }}$ day and then gradually decreased.

Meanwhile, ACC oxydase activity of all AVG spraying treatments almost unchanged at the beginning of storage period when fruits have just been harvested, it rapidly increased and reached its peak at pre-climacteric stage. After reaching the peak, ACC oxydase activity gradually declined. The specific results are following:

When the fruits are sprayed with AVG on the $70^{\text {th }}$ day, ACC oxydase activity reached the maximum value at 2.59 nmol $\mathrm{C}_{2} \mathrm{H}_{4} \cdot \mathrm{g}^{-1} \cdot \mathrm{h}^{-1}$ on the $28^{\text {th }}$ day of storage.

When the fruits are sprayed with AVG on the $74^{\text {th }}$, ACC oxydase activity reached the maximum value at 2.67 nmol $\mathrm{C}_{2} \mathrm{H}_{4} \cdot \mathrm{g}^{-1} \cdot \mathrm{h}^{-1}$ on the $34^{\text {th }}$ day. 
When the fruits are sprayed with AVG on the $78^{\text {th }}$, ACC oxydase activity reached the maximum value at 2.93 nmol $\mathrm{C}_{2} \mathrm{H}_{4} \cdot \mathrm{g}^{-1} \cdot \mathrm{h}^{-1}$ on the $36^{\text {th }}$ day.

When the fruits are sprayed with AVG on the $82^{\text {nd }}$, ACC oxydase activity reached the maximum value at 2.45 nmol $\mathrm{C}_{2} \mathrm{H}_{4} \cdot \mathrm{g}^{-1} \cdot \mathrm{h}^{-1}$ on the $30^{\text {th }}$ day.

It can be concluded that spraying AVG on banana at pre-harvest period from $74^{\text {th }}$ to $78^{\text {th }}$ days helped to inhibit ACC oxydase activity that lead to inhibition of ethylene biosynthesis process. As a result, the ripening process was delayed and the shelf - life of banana fruit was prolonged accordingly.

\section{Conclusions}

The most appropriate time to spray AVG is from the $74^{\text {th }}$ to $78^{\text {th }}$ day (after cutting flower) because at this period, AVG shows the high inhibitory effect of ACC, ACC oxydase and ethylene synthesis.

ACC content, ACC oxydase and ethylene production of banana treated with AVG $0.8 \mathrm{~g} / 1$ by spraying on the $78^{\text {th }}$ day, stored at $13 \pm 1^{\circ} \mathrm{C}$ for 28 days were $1.09 \mathrm{nmol} \mathrm{C} \mathrm{H}_{4} \cdot \mathrm{g}^{-1}, 0.44 \mathrm{nmol} \mathrm{C}_{2} \mathrm{H}_{4} \cdot \mathrm{g}^{-1} \cdot \mathrm{h}^{-1}$ and $0.11 \mu \mathrm{l} \mathrm{C}_{2} \mathrm{H}_{4} \cdot \mathrm{kg}^{-1} \cdot \mathrm{h}^{-1}$ respectively while the results for non-treated fruits were $6.89 \mathrm{nmol} \mathrm{C}_{2} \mathrm{H}_{4} \cdot \mathrm{g}^{-1}, 2.18 \mathrm{C}_{2} \mathrm{H}_{4} \cdot \mathrm{g}^{-1} \cdot \mathrm{h}^{-1}$ and $1.48 \mu \mathrm{l}$ $\mathrm{C}_{2} \mathrm{H}_{4} \cdot \mathrm{kg}^{-1} \cdot \mathrm{h}^{-1}$ respectively.

\section{References}

Barker L.R. (2002). Postharvest technical training handbook. Queensland Department of Primary Industries (QDPI, Australia).

Blankenship S. (2000). Ethylene: The Ripening Hormone. Tree Fruit Research and Extension Center, Washington State University.

Capitani G.., Darla L., McCarthy, Heinz G., Markus G. G. \& Jack F. K. (2002). Apple 1-Aminocyclopropane-1-carboxylate synthesis in complex with the inhibitor L-aminoethoxyvinylglycine. The journal of biological chemistry, Vol.227, No 51, pp. 49735 - 49742.

Innaba, A., L. Xuejun, N. Yokotani, M. Yamane, W. J. Lu, R.i Nakano andY. Kubo. (2007), "Differential feedback regulation of ethylene biosynthesis in pulp and peel tissues of banana fruit", Journal of Experimental Botany, Vol.58, No.5, pp.1047 - 1057.

Jobling. J, Pradhan R., Morris S. C., Mitchell L. \& A. Rath A.C. (2003). The effect of Retain plant growth regulator aminoethoxyvinylglycine (AVG) on the postharvest storage life of 'Tegab Blue' plums. Australian Journal of Experimental Agriculture, Vol.43, No 5, pp. 515-518.

Lizada M.C.C., Yang S. F. (1979). A simple and sensitive assay for 1-aminocyclopropane-1-cacboxylic acid. Analytical Biochemistry, Vol.100, pp.140 -145.

McGlasson W.B., Rath A.C. \& Legendre L. (2005). Preharvest application of aminoethoxyvinylglycine (AVG) modifies harvest maturity and cool storage life of 'Arctic Snow' nectarines. Postharvest Biology and Technology, Volume 36, Issue 1, pp. 93-102.

Mizutani F., Jian G. D. \& Yang S. F. (1995). Effect of $\mathrm{pH}$ on $\mathrm{CO}_{2}$-actiavated-1-aminocyclopropane-1-carboxylate oxydase activity from apple fruit, Phytochemistry, Volume 39, Issue 4, pp. 751-755.

Moya-León MA., John P. (1994). Activity of 1-aminocy clopropane-1-carboylate (ACC) oxydase (ethyleneforming enzyme) in the pulp and peel of ripening bananas, Journal of Horticultural Science, Vol.69, No. 2, pp.243-253.

Ness, J.P and Roger J. Romani. (1980), "Effects of Aminoethoxyvinylglycine and Countereffects of Ethylene on Ripening of Bartlett Pear Fruits", Plant Physiology, Vol.65, pp.372 - 376.

Toan N.V., Hoang L.V., Tan L.V., Thanh L.T.Lien,Thanh C.D \& Hanh T.M. (2009). Effects of Retain - AVG (aminoethoxyvinylglycine) on the storage time of banana (Musa cavendish AAA) after harvert. Journals of Science and Technology (Viet Nam), Vol. 47, No. 1, pp. 27-33.

Toan N.V., Thanh C.D., Hoang L.V., Tan L.V., Hanh T.M., Thanh L.T.L \& Anh T.T. Q. (2010). Effects of near-harvest application of aminoethoxyvinylglycine (AVG) on banana Fruits during postharvest storage. Acta Horticulture, Vol.875, No.1, pp. 163-168.

Tong, R.C. (2010). The effects of aminoethoxyvinylglycine (AVG) and 1- methylcyclopropene (1-MCP) on banana ripening, Department of Botany and Plant Biotechnology, DigiSpace at the University of Johannesburg. 
Table 1. Effect of AVG spraying time on ACC oxydase activity of banana during postharvest storage

\begin{tabular}{|c|c|c|c|c|c|c|c|}
\hline Storage time & Control & $70^{\text {th }}$ day & $74^{\text {th }}$ day & $78^{\text {th }}$ day & $82^{\text {nd }}$ day & $\mathrm{CV} \%$ & $\mathbf{L S D}_{0.05}$ \\
\hline Day 0 & $0.12^{\mathrm{a}}$ & $0.19^{\mathrm{a}}$ & $0.08_{\mathrm{a}}$ & $0.05^{\mathrm{a}}$ & $0.09^{\mathrm{a}}$ & 2.67 & 0.15 \\
\hline Day 2 & $0.26^{\mathrm{a}}$ & $0.29^{\mathrm{a}}$ & $0.10^{\mathrm{b}}$ & $0.06^{b}$ & $0.13^{b}$ & 2.24 & 0.11 \\
\hline Day 4 & $0.31^{\mathrm{a}}$ & $0.37^{\mathrm{a}}$ & $0.15^{\mathrm{b}}$ & $0.09^{b}$ & $0.12^{\mathrm{b}}$ & 2.24 & 0.14 \\
\hline Day 6 & $0.38^{\mathrm{a}}$ & $0.43^{\mathrm{a}}$ & $0.16^{\mathrm{b}}$ & $0.10^{\mathrm{b}}$ & $0.15^{\mathrm{b}}$ & 2.14 & 0.12 \\
\hline Day 8 & $0.47^{\mathrm{a}}$ & $0.49^{\mathrm{a}}$ & $0.15^{\mathrm{b}}$ & $0.12^{\mathrm{b}}$ & $0.21^{\mathrm{b}}$ & 2.16 & 0.15 \\
\hline Day 10 & $0.50^{\mathrm{a}}$ & $0.53^{\mathrm{a}}$ & $0.21^{\mathrm{b}}$ & $0.14^{\mathrm{b}}$ & $0.26^{\mathrm{b}}$ & 2.12 & 0.12 \\
\hline Day 12 & $0.63^{\mathrm{a}}$ & $0.67^{\mathrm{a}}$ & $0.27^{\mathrm{b}}$ & $0.18^{\mathrm{b}}$ & $0.29^{\mathrm{b}}$ & 2.18 & 0.25 \\
\hline Day 14 & $0.75^{\mathrm{a}}$ & $0.77^{\mathrm{a}}$ & $0.31^{\mathrm{b}}$ & $0.20^{\mathrm{b}}$ & $0.35^{\mathrm{b}}$ & 2.19 & 0.24 \\
\hline Day 16 & $0.92^{\mathrm{a}}$ & $0.91^{\mathrm{a}}$ & $0.40^{\mathrm{b}}$ & $0.22^{\mathrm{b}}$ & $0.46^{\mathrm{b}}$ & 2.17 & 0.27 \\
\hline Day 18 & $0.94^{\mathrm{a}}$ & $0.99^{\mathrm{a}}$ & $0.43^{\mathrm{b}}$ & $0.24^{\mathrm{b}}$ & $0.52^{\mathrm{b}}$ & 2.25 & 0.36 \\
\hline Day 20 & $0.99^{\mathrm{a}}$ & $1.03^{\mathrm{a}}$ & $0.50^{\mathrm{b}}$ & $0.32^{\mathrm{b}}$ & $0.57^{\mathrm{b}}$ & 2.24 & 0.37 \\
\hline Day 22 & $1.15^{\mathrm{a}}$ & $1.18^{\mathrm{a}}$ & $0.53^{\mathrm{bc}}$ & $0.32^{\mathrm{c}}$ & $0.70^{\mathrm{b}}$ & 2.12 & 0.26 \\
\hline Day 24 & $1.68^{\mathrm{a}}$ & $1.27^{\mathrm{b}}$ & $0.67^{\mathrm{c}}$ & $0.35^{\mathrm{d}}$ & $0.80^{\mathrm{c}}$ & 2.06 & 0.22 \\
\hline Day 26 & $2.86^{\mathrm{a}}$ & $1.78^{\mathrm{b}}$ & $0.77^{\mathrm{c}}$ & $0.36^{\mathrm{d}}$ & $0.92^{\mathrm{c}}$ & 2.04 & 0.24 \\
\hline Day 28 & $2.18^{\mathrm{b}}$ & $2.59^{\mathrm{a}}$ & $0.84^{\mathrm{d}}$ & $0.44^{\mathrm{e}}$ & $1.54^{\mathrm{c}}$ & 2.05 & 0.35 \\
\hline Day 30 & $1.95^{\mathrm{a}}$ & $2.07^{\mathrm{a}}$ & $0.96^{\mathrm{b}}$ & $0.56^{\mathrm{b}}$ & $2.45^{\mathrm{a}}$ & 2.11 & 0.55 \\
\hline Day 32 & - & $1.79^{\mathrm{c}}$ & $1.46^{\mathrm{b}}$ & $0.60^{\mathrm{d}}$ & $2.23^{\mathrm{a}}$ & 2.10 & 0.37 \\
\hline Day 34 & - & - & $2.67^{\mathrm{a}}$ & $1.21^{\mathrm{c}}$ & $1.98^{\mathrm{b}}$ & 2.18 & 0.43 \\
\hline Day 36 & - & - & $2.28^{\mathrm{b}}$ & $2.93^{\mathrm{a}}$ & $1.35^{\mathrm{c}}$ & 2.42 & 0.53 \\
\hline Day 38 & - & - & 2.08 & 2.16 & - & & \\
\hline Day 40 & - & - & - & 1.87 & - & & \\
\hline Day 42 & - & - & - & 1.23 & - & & \\
\hline
\end{tabular}

(In the same row, means with a same letter are not significantly different at $p \leq 0.05$ ) 




Figure 1. Effect of AVG spraying time on ethylene production of banana during postharvest storage

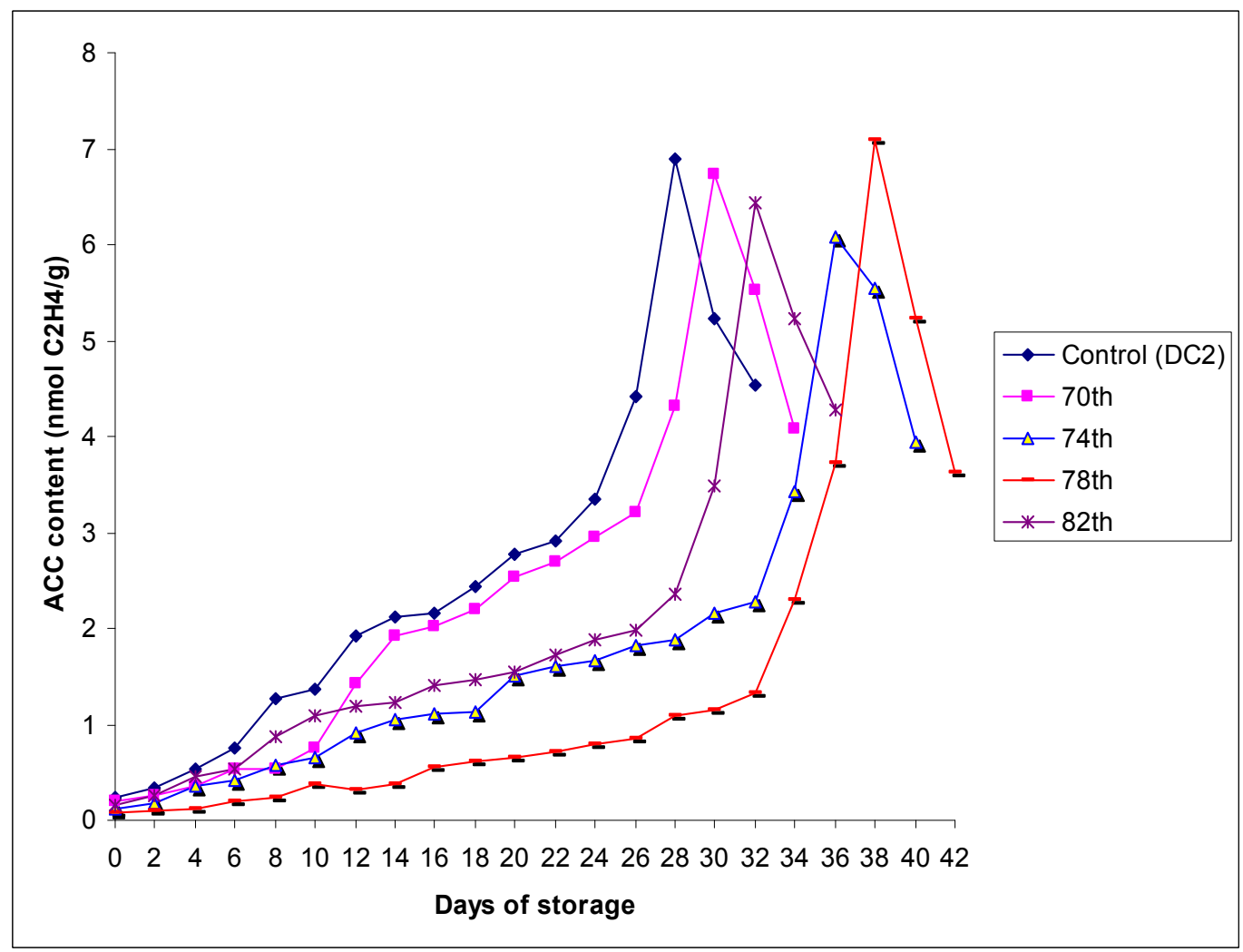

Figure 2. Effect of AVG spraying time on ACC content of banana during postharvest storage 